\title{
As invenções da guerra: reflexões sobre um jogo carnavalesco
}

\section{The inventions of war: reflections on a carnival play}

Luiza Dias Flores - Doutora em Antropologia Social, pela Universidade Federal do Rio de Janeiro (Museu Nacional/UFRJ). Professora substituta na Universidade Federal de Goiás (UFG). E-mail: ldiasf@gmail.com.

\section{Resumo}

Esse artigo recupera alguns dados da minha dissertação de mestrado para apresentar um jogo singular, chamado "guerra", que acontece na cidade de Porto Alegre, no Rio Grande do Sul, protagonizado pelas tribos carnavalescas, que existem desde a década de 1950 e eram as principais atrações do carnaval da cidade. Hoje, contudo, existem apenas duas, "Os Comanches" e "Os Guaianazes". O trabalho etnográfico que aqui apresento acompanha os processos criativos da tribo "Os Comanches" durante o carnaval de 2012. Pretendo apresentar como o jogo, a guerra, funciona enquanto um dispositivo de invenção de elementos considerados "afro" e "indígenas", elementos esses que só existem em relação entre si.

\begin{abstract}
This article recovers some data from my master's dissertation to present a singular play-ritual, called "war", that takes place in the city of Porto Alegre, in Rio Grande do Sul, starring carnival tribes, which have existed since the 1950s and were the main attractions of the city's carnival. Today, however, there are only two, "The Comanches" and "The Guaianazes". The ethnographic work that I present here accompanies the creative processes of "The Comanches" tribe during the carnival of 2012. I intend to present how the play-ritual, war, works as a device for the invention of elements considered "afro" and "indigenous" elements, which only exist in relation.
\end{abstract}

\section{Keywords}

Jogo. Tribos Carnavalescas. Carnaval. Afroindígena.

\section{Palavras-chave}

Play. Carnival Tribes. Carnival. Afroindigenous. 


\section{INTRODUÇÃO}

Trato aqui das tribos carnavalescas em Porto Alegre, grupos que, desde a década de 1940, se vestem de índios norte-americanos para fazer o carnaval e se autodenominam "índios" e "guerreiros". As tribos carnavalescas são conhecidas pela bibliografia sobre o carnaval gaúcho como "remanescentes do carnaval afroindígena da cidade", porém há raríssimos trabalhos dedicados exclusivamente a elas e, aqueles que as citam, tratam de sua importância histórica no carnaval do estado. Fato é que não há trabalho que se dedique a apresentar como as tribos contemporâneas se produzem "indígenas"” no carnaval de Porto Alegre, questão que tentei desenvolver ao longo de seis meses de trabalho de campo no bairro São José, periferia de Porto Alegre, onde está situada a sede de "Os Comanches", também denominada Taba de Urupá. Realizei entrevistas, observações, e, sobretudo, tive uma convivência intensa com os comancheiros, majoritariamente moradores do bairro São José.

Se entre os anos 1940 e 1950 existiram cerca de 17 tribos, hoje resistem apenas duas, "Os Comanches" e "Os Guaianazes". Em especial, trabalho com a tribo "Os Comanches", fundada em 1959, cujo nome foi escolhido em referência à tribo da América do Norte, divulgada para os "índios carnavalescos" por meio de gibis e filmes de faroeste. Como me disse o "cacique" da tribo, gostavam de admirar "aqueles guerreiros fortes e fantasiados". Trato, aqui, de um jogo que acontece anualmente no carnaval da cidade de Porto Alegre (RS), chamado "guerra". O conceito de jogo, aqui, funciona como um tempo-espaço que “implica relações e não é apenas explicado por elas” (GEIGER, 2006, p. 38).

Interessam-me os processos de articulação e desarticulação envolvidos na produção da "guerra", onde o ritual não serve a uma integração, mas onde integração e desintegração são dois processos comunicativos concomitantes. A "guerra" é pautada pela rivalidade existente entre as duas tribos restantes: "Os Comanches" e "Os Guaianazes". Essa rivalidade se estende para além do ritual, mas é contrabalançada por um forte vínculo de interdependência entre ambos. Se uma tribo desiste de guerrear, a outra, inevitavelmente, também deixará de existir.

\footnotetext{
1 Ainda assim, é fundamental ressaltar que a presença indígena na literatura sobre o carnaval aparece desde os folcloristas, como Guerra-Peixe, Katarina Real, Mário de Andrade, Câmara Cascudo, aos trabalhos mais recentes. Destaco alguns sobre Blocos de índio no Rio de Janeiro (ver PEREIRA, 2002) e na Bahia (ver RISÉRIO, 1981; GODI, 1991; SILVA, 2004), sobre os Caboclinhos (ver SANTOS, 2008; ACSELRAD, 2017) e Maracatus (ver SILVA, 2018) no Recife, e outras tantas manifestações nos carnavais brasileiros (ver ALMEIDA, 1961).
} 
Dessa forma, as relações de rivalidade e interdependência são concomitantes e produzem a continuação das "guerras".

Descrevo uma forma muito particular de fazer o carnaval, um carnaval "de índio", cuja rivalidade ${ }^{2}$ é a principal característica. É interessante perceber que a "guerra" dos "índios" ocorre por meio da produção artística e não carrega como correlato a paz. Não visa, portanto, nenhuma forma de integração completa entre as partes em disputa. Tomo a "guerra" dos "índios carnavalescos" como um jogo, definido por Bateson (1991), que ocorre na avenida e é experienciado a partir de dois níveis de abstração - o jogo, vivido como "território" (como coisa em si), e o jogo vivido como "mapa" (como metáfora) ${ }^{3}$. O que separa um do outro é um marco de referência, pautado por um espaço-tempo do carnaval (os dias de desfile e o local onde esse ocorre).

"Jogo", para Bateson (1991), é uma sequência de interações cujos sujeitos envolvidos percebem que os signos com que se metacomunicam são sinais. Sabem que a "guerra" não é a batalha indígena, muitas vezes documentada pelos etnólogos e romantizada pelos nossos escritores, ela é entendida com "mapa", e não como “território". Porém, diz Bateson:

Se segue, por consequência, que o marco do jogo tal como se emprega aqui enquanto princípio explicativo supõe uma combinação especial do processo primário e do secundário. Mas isso guarda relação com o dito, anteriormente, quando se sustentou que o jogo marca um passo adiante na evolução da comunicação, o passo crucial no descobrimento das relações mapa-território. No processo primário, o mapa e o território se identificam; no processo secundário, podem ser discriminados. No jogo, se identifica e se discrimina tais processos (BATESON, 1991, p. 137, tradução nossa).

No início do meu trabalho de campo era comum os comancheiros apresentarem a "guerra" a partir dos aspectos de "mapa" do jogo, ou seja,

2 Aqui é importante outro adendo. A rivalidade é fato constituinte de uma série de manifestações carnavalescas no Brasil e também em outros contextos rituais. Não caberia aqui fazer um resgate dessa discussão. O interessante, contudo, é pensar como a rivalidade toma forma e se manifesta entre os sujeitos dessa pesquisa.

3 Impõe-se o problema dos "mapas" e "territórios" abordados por Bateson (1991), ou da relação entre Pleroma e Creatura. Para o autor, Pleroma é os mundos das "coisas em si", do território, causado por forças e impactos, e não contém descrições. Pleroma pode ser usado como sinais ou pode ser descrito, mas ele, por si só, nada faz. Creatura é o mundo das relações, das ideias e da comunicação (verbal e pré-verbal). Pleroma e Creatura são instâncias imbricadas uma na outra: só sabemos da existência do Pleroma a partir da Creatura, a partir de metáforas e, ao mesmo tempo, a Creatura só existe no interior de um Pleroma: ambos se afetam mutuamente. A questão que nos interessa a partir das ideias de Bateson é que a produção de conhecimento passa por uma comparação de diferenças, metáforas (informações), e não entre "coisas em si" (BATESON, 1991, 1989). 
falavam que o padrão de comportamento posto na "guerra", a rivalidade, existia apenas na avenida e que as tribos "se davam bem" para além do carnaval. Como se houvesse uma realidade externa ao jogo em que a rivalidade entre as tribos não se encontra. Porém, o próprio marco de referência é posto em questão, principalmente quando afirmam, assim como ouvi do cacique, de que "carnaval é todo o ano". Da mesma forma, em diversas situações em que certos sujeitos da tribo rival não eram bem-vindos em território comancheiro e vice-versa. As fronteiras da realidade do jogo tornam-se porosas. É essa porosidade que a "guerra" resguarda, pois o interessante do jogo é que ele agrega, em verdade, esses dois níveis de abstração que existem em um constante processo de identificação e discriminação, onde o jogo é mapa e é território.

Neste artigo apresentarei aspectos centrais na construção do jogoritual "guerra". Para que ele exista, os guerreiros desenvolvem uma série de metaforizações, invenções, entre elementos considerados "afros/negros" e elementos considerados "índios"; metaforizações essas que alimentam a rivalidade entre os "índios" e fazem com que a "guerra" aconteça. Concebo a invenção, e, portanto, a transformação que produz, como constituinte do modo de conhecer e pensar do humano. A invenção nada mais é do que a forma da experiência e entendimento humano e, assim, pode ser concebida em um sentido menos denunciatório - com o intuito de atestar "falsidade", como se fossem engendradas por interesses estratégicos, não correspondendo à história "real" que diz respeito a um dado grupo. Se pensada com Roy Wagner (2010), a invenção, e a dialética que lhe dá forma - a relação entre modo de simbolização convencional e modo de simbolização diferenciante -, torna-se uma condição da "cultura", tal como inventamos o outro a partir de nossa própria criação do conceito de "cultura".

4 Para Wagner (2010, p. 81), o significado é contingente às formas simbólicas e pode somente ser invocado por meio de símbolos, baseados no princípio da simbolização. O processo de invenção é da ordem de sucessivas metamorfoses simbólicas e é baseada na criatividade que engendra. Com isso, pontua que a "cultura" existe a partir de dois modos de simbolização, denominados por ele como convencional e diferenciante. A primeira relaciona signos dentro de um determinado padrão, uma vez que fornece uma "base relacional coletiva". Tal simbolização convencionaliza associações e permite que os símbolos sejam compartilhados, fornecendo a base comunicacional dos sujeitos. Ou seja, os símbolos convencionais coletivizam. Isso não implica em dizer que existem significados primários ou originários, pois os significados são produtos das relações e são constantemente estendidos para outros contextos. O que a convenção proporciona nada mais é que a "ilusão de que algumas associações de algum elemento simbólico são primárias e auto-evidentes (WAGNER, 2010, p. 80). Há, entretanto, outro modo de simbolização, chamado diferenciante. Nesse modo, como ocorre na criação da metáfora, os símbolos englobam as coisas que simbolizam ao representar apenas eles mesmos. As simbolizações convencionais e diferenciantes são interdependentes entre si na medida em que os símbolos para serem comunicados necessitam ser compartilhados e produzir convenções. 
Dessa forma, podemos compreender a "cultura" como sucessivos processos de metaforizações, em uma dialética entre esses dois modos de simbolização, onde utilizamos símbolos convencionais para inventar e, ao mesmo tempo, inventamos a própria convenção. Neste sentido, um significado não-tautológico só pode ser produzido por meio da "extensão inovativa" dos significantes em metáforas, isto é, da formação de símbolos que contrasta com os elementos significados é suplementado por uma relação de similaridade ou analogia com esse elemento, na medida em que é estendido para outros contextos. Derivamos disso que a substituição é a essência da invenção.

O que a convenção proporciona nada mais é do que a "ilusão de que algumas associações de algum elemento simbólico são primárias e auto-evidentes" (WAGNER, 2010, p. 80). Essas generalizações e modos de coletivizar lembramnos das atribuições do carnaval como elemento constituinte da "cultura negra", como encontramos no carnaval de Porto Alegre. Isso dá a esse mundo uma organização, um padrão, uma "ilusão necessária” coletivizante. Todavia, essas convenções existem apenas a partir de suas invenções. É necessário inventar a convenção (pois é essa que dá consistência ao mundo), da mesma forma que a convenção serve de arcabouço para a invenção de novos significados. É uma dialética sem síntese, onde a convenção incita a invenção e vice-versa. Por isso, a ideia de arcabouço de símbolos que a convenção passa a ter é entendida pelo autor como uma ilusão necessária para a produção de invenções.

Tal dialética sem síntese de Roy Wagner (2010) é interessante para pensarmos as transformações que ocorrem no carnaval, em que a capacidade inventiva dos comancheiros é o que sustenta a "guerra". "Índio, índio mesmo é negro", fala dona Georgina, esposa do cacique. Sua fala é um disparate para a antropóloga que supõe verdades sobre o outro e afirma que eles, 'na verdade são negros' e 'representam' índios. No caso dos comancheiros, quando dizem que "índio, índio mesmo é negro", produzem uma extensão metafórica, inventam "índio" a partir do "negro", da mesma forma contrainventam "negro" a partir de "índio". Tal complementariedade entre "afro" e "índio" constitui os processos inventivos dos comancheiros na "guerra" e, ao mesmo tempo, reforça a relação de rivalidade com os Guaianazes. Relações afroindígenas dinâmicas que fazem com que a "guerra" aconteça. Um tanto dessas invenções é o que desejo descrever. 
Todo carnaval inicia com a escolha de um "tema-enredo". Os ensaios na tribo iniciam em outubro, porém, antes disso, os comancheiros já elaboram o que será abordado. O tema é produto de uma pesquisa sobre as lendas e as histórias indígenas e transpostas em forma de rima para uma canção. Normalmente é uma única pessoa que realiza a pesquisa e produz a letra e, posteriormente, a canção é composta em conjunto e discutida pelos integrantes da harmonia, o ensaiador e o pesquisador do tema. Foi o cacique Brasil quem escreveu o tema “O sonho de Paraguassu" para o carnaval de 2012. Em resumo, segundo contam, Paraguassu sonhou que um navio sofreu um acidente e que a Virgem Maria, com o menino Jesus, pediu para que Caramuru - o homem "branco" que se casou com Paraguassu - fosse até o navio a salvasse e a levasse para a tribo, onde ela deveria ficar. Há uma narrativa contada por meio do desfile.

No dia da apresentação, foi dada a sirene para a tribo entrar na avenida. "Arassuaia, arassuaia, a nossa história começa bem assim: o sonho de Paraguassu! O sonho de Paraguassu! Apuracê! Curimá!”, diz Jaguarema, o ensaiador. Foi dado o início da "guerra". "Arassuaia" é para pedir atenção, "Apuracê, curimá" é para "chamar as cordas" da harmonia - composta por dois violões e dois cavacos, além de cinco cantores, dentre eles o "puxador", o cantor principal. São "palavras indígenas" de comando ${ }^{5}$. Todos os "guerreiros" estavam a postos em suas respectivas alas e os carros alegóricos prontos para serem apresentados na avenida. O sinal foi dado: era o início dos 55 minutos de "guerra", para o qual os "índios carnavalescos" se preparavam muitos meses. A "guerra" é feita por "guerreiros" e sua apresentação segue a estrutura de alas, bem como as escolas de samba. Dizem os comancheiros que foi por influência delas que começaram a organizar o desfile por alas, visto as exigências do júri. Ao mesmo tempo, há inúmeras diferenças entre o desfile da primeira e da segunda e essa é uma questão sempre lembrada pelos "índios" para demarcarem sua diferença com as Escolas, que são "mais afro". Além da narrativa visual e a narrativa melódica da canção, conhecida como "hino", há também a "macumba", principal elemento que os diferencia das escolas de samba. Trata-se de uma espécie de "teatro indígena" que encena o "tema" em frente aos jurados, e marca outra cadência rítmica, mais lenta.

5 A escrita dessas palavras é livre e minha, na tentativa de seguir a forma como meus interlocutores falavam.

6 Coincidência, ou não, é de se destacar que entre os caboclinhos de Pernambuco existem diferentes marcações ritmas denominadas guerra, baião, perré e macumba (SANTOS, 2008; ACSELRAD, 2017). Entre as tribos, as principais diferenciações rítmicas são entre o "hino" e a "macumba". 
Na apresentação de 2012, a "macumba" procedera da seguinte forma: a Virgem Maria, representada pela neta de dona Georgina e seu Valdir, aparecia na gruta, representada pelo segundo carro alegórico, em meio à fumaça branca, e se dirigia ao terceiro carro, representação da aldeia indígena. Quando chegou ao terceiro carro, novamente uma fumaça amarela foi lançada, simbolizando a chegada da Virgem Maria. Todo o "teatro indígena" é realizado em frente aos jurados, convidados pela Associação dos Carnavalescos do município, para ser julgado. A "macumba" é a característica principal da performance dos "índios carnavalescos". Se perguntarmos a qualquer integrante o porquê de eles serem considerados "índios", uma das primeiras respostas dadas será "porque a gente faz a macumba, que é tipo um teatro indígena". Após a "macumba", novamente a bateria acelerou o ritmo e Arapuã, o puxador, fez a chamada para iniciar o "hino". Se a "guerra" se apresenta dessa forma, como ocorre pragmaticamente esse engajamento inventivo na sua feitura? Como a "guerra" é produzida? Que elementos estão implicados na produção desse jogo? Quais os procedimentos, nos termos comancheiros, dessa invenção?

\section{FAZER “CRESCER” A IDEIA}

"Guerrear" é inventar. "No carnaval ninguém sabe nada, pois sempre se está aprendendo", diz o cacique com sua autoridade de mais de 50 anos de carnaval. Por isso a observação é essencial para se produzir um bom desfile, pois somente assim é possível perceber novas formas de trabalhar os antigos materiais ou até mesmo descobrir novos. Contam que, no passado, para criar os cocares, passavam noites em claro para "dobrar arames". Hoje a facilidade do papelão dispensa qualquer trabalho árduo. Essas constantes inovações alertam o sujeito para outros modos possíveis de criar o carnaval. Devido a essas inovações, segundo o cacique, o bom carnavalesco não é aquele que domina uma determinada técnica, mas quem é capaz de se abrir para as novidades e trabalhar com o inesperado. A inovação acaba tendo como correlato a improvisação, pois os comancheiros precisam criar a partir dos materiais disponíveis que, normalmente, provêm de sobras de fantasias ou materiais das Escolas de Samba ou de sobras de festas realizadas no bairro, além de uma pequena porcentagem de compras que a tribo realiza com o dinheiro recebido pela AECPARS ${ }^{7}$.

\footnotetext{
A Associação das Entidades Carnavalescas de Porto Alegre e do Rio Grande do Sul (AECPARS) recebe uma verba da Secretaria de Cultura da Prefeitura de Porto Alegre destinada ao carnaval.
} 
O que aparece em evidência nas técnicas utilizadas para a criação das alegorias e fantasias é uma constante preocupação dos interlocutores em inventarem um carnaval "de índio", afastando-se do que seria um carnaval "mais afro", como "de escola de samba". Ao receberem sobras das escolas de samba, os sujeitos utilizam tais materiais para produzirem coisas "de índio", ainda que sejam sobras de outros coletivos "mais afros". Tomam-nas com forma prévia “mais afro", para inventá-las de outro modo, torná-las “de índio". Tudo é feito "indigenamente", dizem. E por meio dessa expressão fica evidente que o modo de produção e aquilo que se produz estão intrinsecamente relacionados. Sem dúvida, as alegorias e as fantasias são elementos fundamentais na "guerra", tanto que muito tempo e disposição dos comancheiros são direcionados para a sua feitura, independente de haver poucas pessoas na arquibancada para admirar seus trabalhos ou de a vida desses artefatos de "guerra" durar apenas os 55 minutos de avenida.

A fantasia dos “índios carnavalescos" segue um modelo mais próximo aos índios norte- americanos. Os comancheiros salientam que isso nem sempre é visto com bons olhos pelos jurados, mas seguem o argumento de que se fossem vestir com roupas de índios brasileiros deveriam desfilar sem roupa. $\mathrm{Na}$ tribo, não adianta muito ter croquis para elaborá-las. São as mulheres da tribo, as mais antigas, que criam as roupas de cada ala a partir de suas "ideias" sobre o tema produzido. Paraquedas, antigo amigo da tribo, morador do bairro e membro fundador do bloco Afro-Sul Odomodê, algumas vezes desenhou modelos de fantasias e cocares para carnavais do passado, mas quem criava mesmo, dizem, era dona Georgina (esposa do cacique e costureira das alas "Itaúna" e "Iracema”), pois "criava em cima da criação do Paraquedas", disse-me ela, "fazia crescer mais a ideia, ficar mais bonito", completou seu marido. O material, comprado pela diretoria da tribo, é distribuído para as diretoras de alas e cada uma elabora as fantasias em articulação com o tema que será apresentado.

Da mesma forma acontece com a elaboração das alegorias, atividade exclusivamente masculina. "Não dá certo essa coisa de seguir modelo", afirmavam o cacique, Urbano e Dogue, os três responsáveis por ficar no "barracão" confeccionando as alegorias. O cacique conta que a criação não se dá apenas no plano da abstração, não basta apenas ter um desenho. É preciso "botar a

Essa verba é dividida entre as escolas de samba e as tribos carnavalescas. As informações que obtive sobre a distribuição das verbas é um tanto confusa, pois falar de dinheiro entre os comancheiros é visto com maus olhos. Recebi a informação, apenas, de que $5 \%$ da verba total recebida eram repassados para as tribos carnavalescas. 
ideia em contato" com os tecidos, com o isopor ou com os materiais que se têm disponíveis para compor as alegorias. "Botar a ideia em contato" é atentar para o fato de que nem tudo está na ideia e nem tudo está no material - não se trata de uma imposição da forma sobre a matéria: é a relação entre os dois que possibilita a criação de alegorias e fantasias dos "índios", é a relação entre os dois que "faz crescer" a ideia, no momento em que a "forma de índio" ganha vida na relação entre material e ideia ${ }^{8}$.

Fazer a "ideia crescer" tem por fim o desfile de carnaval. "Não tem satisfação maior que ver passar na avenida algo feito por mim, pelas minhas mãos, serrando madeira, pintando, erguendo", disse, certa vez, Urbano, "mesmo a plateia estando meio vazia", como foi o caso do desfile de "Os Comanches". Ele preferiria a arquibancada lotada, vibrando, mas o importante mesmo é que o trabalho dele estava na avenida, "e estava bonito". Trabalho este produzido no "barracão", onde "se entrega a alma para o carnaval", como lembrou, emocionado, Marcelo - que não pôde participar das construções das alegorias por conta do trabalho que exerce como segurança. "A gente apresenta um pouco da gente", salientou Urbano, no mesmo momento de conversa. Entretanto, o estatuto que as coisas têm no carnaval carregam certa especificidade que é importante pontuar: o tempo de sua duração. Nesse sentido, a percepção comancheira faz eco aos carnavalescos cariocas, ouvidos por Cavalcanti, no modo como percebem suas alegorias:

A existência plena do carro alegórico não é reprodutível. Ele só existe na duração ritual e massivamente compartilhada de sua passagem pelo mundo. É totalmente singular, não deseja passado, não almeja futuro, é só presente. Porém deseja, aí sim, abolir a permanência. E tudo o que é nada mais será. Para que um novo carnaval possa acontecer (CAVALCANTI, 2006, p. 25).

Ali não são objetos inertes ao mundo, mas carros-na-avenida. Tenho a sensação, pelas falas de meus interlocutores, que a "ideia cresce" quando em

\footnotetext{
8 Semelhante ao dissertado por Mello (2010) junto ao Movimento Cultural Arte Manha em Caravelas, no sul da Bahia. Em seu trabalho, a autora aponta para os modos de criações dos escultores de madeira morta do movimento cultural: "a criação, portanto, não é o resultado de um projeto previamente definido; é, antes, o produto da relação que se estabelece no momento em que as ideias e habilidades do artista se encontram com a forma dada pela madeira" (MELLO, 2010, p. 234). Em outro momento a autora coloca: "além de ser um meio para se atribuir uma nova vida e sentido para um ser anteriormente jogado, esquecido, o processo de criação realiza uma espécie de revelação da forma que está escondida ou em potência na madeira bruta. Uma espécie de diálogo se estabelece com a 'natureza' durante o processo criativo, no momento em que o artista observa a forma da madeira e tenta auscultar seu sentido implícito, a forma que a 'natureza está dando' e que precisa ser revelada" (MELLO, 2010, p. 237).
} 
contato com o material, mas ela ganha vida ${ }^{9}$ quando apresentada na avenida, pois é ali que a "guerra" acontece nos 55 minutos de apresentação, em que a "ideia crescida" é apresentada ao público e ao júri e posta em avaliação no que possuem de "índio", que só existe em contraposição ao "afro" das escolas de samba que, é importante dizer, são aquelas que detêm maior status no carnaval da cidade. A passagem na avenida é o auge da improvisação e os carros e fantasias são dados a ver em seu movimento, naquilo que fazem - produzem "índios guerreiros".

\section{A DANÇA, O RITMO E SUAS POROSIDADES}

A dança é um dos elementos centrais na composição da "guerra". De modo geral, os "guerreiros" na avenida dançam com passos binários marcados, como se estivessem em marcha. Dançam para se fazerem índios, para demonstrar suas habilidades estéticas, para provocar a inveja do adversário, para agradar aos olhos da plateia e dos jurados - aqueles que os avaliarão. Porém, há danças específicas de algumas personagens de destaque na avenida. Focarei aqui em duas figuras principais que participam do desfile dos Comanches: o feiticeiro e o casal indígena. Para a criação da dança, há uma forte importância da religião de matriz africana (incluindo o Batuque e a Umbanda, visto que há uma grande preponderância no Rio Grande do Sul de casas de religião da chamada "Linha Cruzada"10). Vale dizer que a relação com a religião passa pelo fato da maioria dos meus interlocutores pertencerem às casas de religião ou terem crescido em meio a essas práticas. É da religião que provém muito do que é concebido enquanto "afro/ negro" para a produção da "guerra" e dos "índios carnavalescos".

No ano de 2012, a participação do "feiticeiro" no carnaval de 2012 possibilitou algumas reflexões interessantes. O "feiticeiro" que desfilou no carnaval desse ano foi adjetivado como "fajuto", pois era um "guri novo" que "não empolga ninguém" e que é "mais branco que tu" [eu, no caso], disse certa vez um dos comancheiros com o intuito de explicar o adjetivo atrelado a ele.

\footnotetext{
Esse conceito de Ingold (2012) faz parte de um paradigma ecológico que tenta pensar as coisas em sua relação com o meio e não separadas dele - em confluência com Bateson (1991), o que temos aqui é o primado da relação. Neste sentido, o carro alegórico e as fantasias parecem ganhar vida, sobretudo, por serem elementos-na-avenida.

10 Uma boa definição sobre a Linha Cruzada é dada por Norton Correa (1998, p. 48). O autor diz que essa expressão religiosa se chama cruzada "porque, enquanto o Batuque cultua apenas Orixás e a Umbanda caboclos e preto-velhos, a Linha Cruzada reúne-os no mesmo tempo, cultuando, além deles, também os exus e as mulheres míticas, as pombas-gira, provavelmente originários da Macumba do Rio de Janeiro". Para maiores informações, a partir de um trabalho etnográfico, ver Anjos (2006).
} 
Esse atual "feiticeiro" é chamado de "fajuto" também por ocupar de improviso o lugar do "feiticeiro" oficial de "Os Comanches". O conheci apenas nos ensaios finais e, depois, nunca mais o vi. "Negrão magro", porte mediano e com seus 60 anos, o feiticeiro "oficial" andava sempre de óculos escuros, mesmo sendo noite, e portava panos brancos amarrados nas mãos para limpar o suor. Dançava de forma frenética. A presença dele era a que mais encantava os comancheiros, pois dançava "como se" estivesse incorporado e fazia a alegria dos espectadores e dos demais. Há quem diga que ele tenha incorporado algumas vezes durante as apresentações, da mesma forma como o antigo dançarino e pai do atual, conhecido como Pai Eli. Havia boatos de que ele não desfilaria nesse ano, porém apareceu nos últimos ensaios para dançar. Sua repentina aparição é explicada por seu Valdir: "não adianta, o sangue ferve no carnaval". Porém, infelizmente, o feiticeiro não compareceu na avenida e por isso foi substituído pelo "feiticeiro fajuto".

Desse fato, podemos reter três elementos centrais para a produção de uma boa performance: o primeiro é ter experiência, ou seja, tempo de carnaval, pois é isso que permite o sujeito improvisar de forma mais convincente, ou "empolgante". O segundo é a atribuição de "branco" ou "negro". Essa não foi a única vez que percebi que isso funcionava como um marcador de boa performance. Aliás, em outros contextos ela foi dita de forma muito mais explícita, o que permitiu compreender melhor a crítica feita ao "feiticeiro fajuto". Por exemplo, é sempre motivo de risada quando há um branco desfilando como "guerreiro". "O pessoal ria quando aparecia um índio-branco, porque índio, índio mesmo é negro", contou dona Georgina. Motivo de maior deboche era quando aparecia a "alemoada", adjetivo para pessoas loiras, para desfilar. Ninguém é impedido de desfilar por conta da pele, porém causa certo estranhamento aos comancheiros quando um "branco" aparece. Nesse sentido, dona Georgina gosta de salientar o fato de que a tribo nada tem a ver com origem étnica indígena, apesar de ela ser descendente dos "índios das Missões" pois quem tem a "pele negra" pode saber desempenhar melhor a performance. Importante salientar que a cor da pele informa, mas não esgota as possibilidades de ser "índio". O "índio" se torna um aspecto mais maleável, pois não é dado na cor de pele apenas, mas é produzida por diversas conexões - com a música, com ambiente, certos movimentos de quadril, pernas e braço, com determinados pertencimentos - que atravessam os corpos.

11 Refere-se aos Sete Povos das Missões, nome que se deu ao conjunto de sete aldeamentos indígenas Guarani, fundados pelos jesuítas espanhóis no atual estado do Rio Grande do Sul. 
O terceiro elemento que se retém a partir do caso do "feiticeiro" é o "como se" estivesse incorporado (de um caboclo, como sugeriu Camisa). O "como se" estivesse incorporado aparece como outra propriedade de uma boa performance. A incorporação sugerida é uma "brincadeira" (também nos comentários de diversos informantes), dizem quando a antropóloga ávida de certezas questiona se ele realmente incorpora um caboclo. "É brincadeira" dizem alguns, "incorpora mesmo", dizem outros rindo. Em um primeiro momento, pensei que a "brincadeira" implicasse em dizer que não é real. Porém, a leitura de Bateson e a de Schechner me fizeram repensar esse estatuto do real. Bateson (1991, p. 36), em seu metadiálogo Por que un cisne? constrói a ideia de que a figura apresentada quando uma bailarina atua como um cisne, tal como no Lago dos Cisnes, apresenta tanto uma "espécie de cisne" e uma "espécie de ser humano". Todos esses aspectos fundem-se na construção da performance e talvez a "brincadeira" possa ser pensada como um jogo de realidades.

Schechner (1995) expande, a meu ver, as questões de Bateson quando propõe que a representação teatral é, em verdade, a apresentação de realidades múltiplas $^{12}$. Todas as realidades são mundos de jogos que são pensados pelo autor como os solos escorregadios do ser contingente e da experiência. Gosto das sugestões de Schechner porque ajudam a refletir com mais seriedade sobre os sentidos do conceito de "brincadeira" na produção da dança do feiticeiro. E suas considerações fizeram-me repensar o estatuto da "brincadeira" entre os comancheiros, não tanto preocupados em separar o real do fictício, mas talvez manipular de forma criativa diversas realidades. Teríamos três realidades entrecruzadas: 1) o mundo daquele que desempenha o papel de feiticeiro, que mora no bairro São José e há muitos anos desfila com os Comanches; 2) o mundo daquilo que se apresenta, ou seja, a própria figura do feiticeiro, do grande xamã da aldeia, capaz de manipular forças da natureza; e 3) o mundo do caboclo, enquanto entidade espiritual da Umbanda, que se apossou do corpo do homem que representa o feiticeiro e que é uma figura atuante na vida de boa parte dos

12 Schechner produz tal pensamento a partir dos conceitos hindus Maia-Lila e sustenta que a tradição indiana rejeita os sistemas rígidos de Ocidente, quadros impermeáveis, metacomunicações inequívocas e regras inscrevendo regimes hierárquicos da realidade. Foi Schutz (1945) apud Schechner (1995) quem cunhou a expressão realidades múltiplas, porém Schechner estabelece um distanciamento em relação ao entendimento do primeiro. Segundo o autor, Schutz encerra as múltiplas realidades cada uma em si, dentro de seus estilos cognitivos próprios, e desconsidera o que faz delas mais poderosas: suas qualidades sistemáticas de transformação a partir de suas interpenetrações. Ainda assim, Schutz teria reduzido tais realidades a uma realidade una (o mundo do trabalho na vida cotidiana) e Schechner, em vez de focalizar sua análise no mundo cotidiano, focará nos sentidos do jogo e das relações existentes entre as realidades múltiplas. 
comancheiros que são vinculados à Linha Cruzada. Inclusive, como disse Camisa, na vida do homem que representa o feiticeiro.

Diferencio essas instâncias para fins argumentativos, mas para "Os Comanches", entretanto, penso ser realidades emaranhadas em uma grande "brincadeira". A boa performance, para meus interlocutores, parece rasurar essas diferenças de mundos, que eu deliberadamente traço, na medida em que o personagem feiticeiro é tomado como um caboclo que é atuante na vida religiosa do homem que desempenha o personagem. Retiramos disso uma situação curiosa: em um primeiro momento um "negrão magro" 'representa' um "feiticeiro indígena". Porém ao colocar em questão a incorporação de um caboclo, as relações se transformam: um "caboclo" (entidade indígena derivada das relações entre Umbanda e Jurema) apossa-se do corpo de um "negrão magro", quando ele está em um momento ritual, o carnaval, desempenhando o papel de um "feiticeiro indígena”. Rasuram-se realidades: será mesmo que o negro 'representa' índio ou um índio se apossa do corpo de um negro para se apresentar no momento ritual? Se a segunda opção for levada a sério, podemos pensar que não apenas o homem negro cria a personagem indígena, mas também que a entidade indígena atua sobre o homem negro que manifesta uma personagem indígena.

A religião também foi acionada por Rosane, bailarina da tribo e componente da terceira figura que desejo apresentar: o casal indígena. Rosane, sobrinha do cacique e filha do Gordo - um dos fundadores da tribo -, é bailarina de "Os Comanches" há 30 anos. Desempenha essa função com maestria há muito tempo e, diversas vezes, foi agraciada pelo troféu de melhor bailarina. Encontrava-a em todos os ensaios, mesmo que não estivesse dançando. Nossa conversa iniciou com sua afirmação de que para criar a "dança indígena" ela misturava "dança candomblé" com os "passos indígenas". Tal mistura foi explicada da seguinte maneira: "porque a gente veio de uma descendência afro, que eram os escravos. Os escravos dançavam para os orixás. E as danças deles também, eram aquela roda, aquele movimento sensual da mulher dançando, a negra dançando, né? O movimento da negra e da índia é semelhante, a sensualidade...”

Essa dança sensual é caracterizada pela improvisação, como nos diz Rosane, em entrevista:

Minha prima é professora de dança e ela queria me ensinar [...] Mas não adianta ensinar porque uma coisa eu vou aprender ali e lá na avenida vou fazer outra coisa. Ela queria me ensinar uns passos mais marcados, coreografados. Mas não adianta [...] É improviso, como se entrasse no 
meu corpo uma Deusa. Porque eu me sinto mesmo uma deusa. [...] Eu sou pronta na religião, filha de Ossanha e recebo caboclo, não no candomblé. Tem uma parte com a Jurema pro lado de caboclo, né, por isso que eu tenho a sensação de índia, né. E acho que tem uma sequência de eu receber caboclo e me sentir índia.

A boa performance, a partir da "energia de índia" suscitada pelo orixá, apresenta com nitidez a porosidade das realidades e a interpenetração entre a espiritualidade de matriz africana e a produção do carnaval. Isso, obviamente, não parece ser alheio às habilidades e estudos que realiza, ou realizou, sobre a "dança indígena" para ser uma boa bailarina, mas também diz respeito à sua participação na religião, ainda que ela dê outra versão, oposta a que ouvi sobre o feiticeiro, sobre o fato da incorporação. Diz ela sobre os orixás e entidades da Umbanda:

No carnaval eles vão embora, né, eles não ficam. Eles vão embora e depois eles voltam. Os trabalhos param todos. Só quem tem Exu que pode trabalhar, mas o resto, todos param. [...] Porque é quaresma, né. Porque daí os orixás vão pra guerra e eles voltam só depois do carnaval. Eles são tão guerreiros quanto nós [risos]. Por isso que eu te disse a aproximação índio e candomblé. São todos guerreiros. Tá explicado, né.

Creio que seja interessante pensar o modo como Rosane conecta religião e carnaval. A colocação "quem tem Exu” se refere a uma das práticas da chamada Linha Cruzada e se refere ao sujeito que incorpora Exu. Os “orixás vão pra guerra” é uma expressão singular dos praticantes do Batuque e se refere a um momento em que todos os trabalhos de terreiro param. Há quem diga que os orixás vão guerrear com os eguns (espíritos dos mortos). Nesse sentido, a participação na religião, que vem da "ancestralidade afro", funciona como o principal contexto cujos elementos são metaforizados, inventados, em "indígena" que, por sua vez, contrainventam o que é "ancestralidade afro". O corpo opera como um lócus onde essas relações são estabelecidas, nas entrecruzas de múltiplas realidades, para a feitura da "brincadeira".

Esse corpo, contudo, encontra-se em profunda composição com a cadência rítmica "indígena”. A preparação para a "guerra" implica ensaios meticulosos da bateria, a "cozinha". Dentro da bateria há uma pequena divisão de gênero e faixa etária entre os participantes, com a preponderância do gênero masculino em sua formação. Homens mais velhos tocavam maracanã e sopapo. Havia apenas um senhor responsável pelo pandeiro. O repinique é tocado 
majoritariamente por meninos entre 12 anos ou mais. Os meninos mais novos, assim como as mulheres e meninas, ficavam responsáveis pelos agês e chocalhos, que são conhecidos como "instrumentos leves". Dentre todos os instrumentos, o agê é o que tem maior importância. Cada ensaiador que passou pela tribo criou um toque "diferenciado" e a única coisa que os une é que não pode sair do "tema indígena". Os Comanches passaram por diversas transformações em seu toque, contou-me o atual ensaiador, Cláudio Camisa. Novamente a improvisação e a invenção aparecem como centrais para os comancheiros.

Há tentativas de interferência por parte dos poderes que organizam e julgam o carnaval das tribos. "Seu" Valdir salientou que antigamente as músicas eram semelhantes às marchas lentas cantadas pelos "guerreiros". Porém, nos carnavais mais recentes um dos jurados sugeriu que o "hino" fosse mais rápido para ser mais empolgante. Esse jurado era um regente de orquestra que fora convidado para o juri do carnaval. Ao falar dele, "seu" Valdir brincou em tom de crítica: "por ele a gente desfilava tocando e lendo partitura! Mas as coisas não funcionam assim, não é assim que é”. Afinal, seria, sobretudo, impedir os movimentos criativos inerentes às tribos.

Para os índios, o que está em jogo é fazer "indigenamente", diferenciandose das escolas de samba, mas também fazer "mais índio" que seu rival. Foi Camisa o criador do atual toque de "Os Comanches", inserindo uma batida "tipo Jeje"13, uma elaboração realizada em cima do toque de "ancestralidade africana" para um som "mais de índio", que consiste em um "compasso binário" demarcado. O conhecimento de Camisa sobre esses toques passa pelo fato de ter sido por muitos anos filho-de-santo, porém "lavou a cabeça" recentemente devido a "desgostos" com a religião. O "compasso binário" de que fala pode ser percebido devido às duas batidas fortes dadas durante a música, feitas pelos instrumentos maiores, como o maracanã. Essas batidas fortes são remetidas aos índios e suas formas de marcar o tempo da música, que marcam também os passos binários da guerra dançada.

A preocupação do ensaiador está em fazer som "de índio". E isso implica se diferenciar das escolas de samba, pois "índio" não toca samba que é um som "mais afro", e ser "mais índio" que a tribo rival. Por conta disso, criticam com veemência os Guaianazes, a tribo rival, por produzirem um "toque morno", sem empolgação. "É que eles não conhecem as rezas da religião, tá entendendo?",

13 Jeje é um toque da religião de matriz africana, do Batuque, e denomina uma das nações que constituíram as religiões de origem africana no Brasil. 
disse Camisa. "As palavras têm que encaixar com o toque e eles não fazem isso, fazem uma batida quase como escola de samba, tchê!". Cláudio Camisa quer produzir um toque que "se encaixe" com as palavras que são verbalizadas. Sua preocupação reside no fato de ensaiadores anteriores de "Os Comanches" - a crítica principal que ele faz é ao Dico, ensaiador de "Os Guaianazes" - produzirem um toque de escola de samba, cuja batida não une a "batida forte" com a sílaba tônica das palavras pronunciadas. Sua explicação pauta-se pelo fato de Dico não conhecer muito a religião. Como disse Camisa, "cada um tira a sua batida de cada reza da religião, só que tu tem que saber as palavras".

Há uma série de variações de toques ao longo da performance na avenida, mas as principais diferenciações podem ser resumidas na "macumba" e no "hino". O "hino" é a base rítmica do carnaval e a "macumba" é um momento de quebra na batida do "hino" e constitui o principal momento do ritual. Segundo Camisa, um dos criadores do toque da macumba dos Comanches, o som se assemelha ao "jeje” da religião de matriz africana, que também serve de base ao "hino", porém de forma mais acelerada. Essas quebras de ritmo fazem o toque da tribo mais complexo do que o toque de escola de samba, visto essa ter um ritmo contínuo, afirma o cacique. "É muito mais difícil ser índio", diz ele. $\mathrm{Na}$ música das tribos, o som dos instrumentos de cordas aparece com mais força no "hino" do que em um samba-enredo das escolas de samba. O tempo da música também é diferente. Enquanto o compasso do samba é "terciário", o "hino" das tribos é marcadamente "binário", como explicou um dos violonistas. Isso é possível de perceber devido às duas marcações fortes dadas pelo instrumento maracanã e pelo agê, que é considerado o "instrumento indígena” por excelência.

O número de agês é alto em comparação com os demais instrumentos e isso ocorre devido à importância dele na execução da "guerra". "Sem agê não se faz tribo", afirma Camisa. Intrigada, perguntei o motivo: "para nós aqui, o agê é de uma origem indígena. Sem os agês, não funciona. É uma parte importante pelo barulho. É por causa desse barulho, a marcação que faz é uma parte essencial da tribo indígena". O agê, em parte, produz o som dos maracás, que são os chocalhos indígenas. Essa substituição ocorreu por conta dos custos em comprar os maracás em comparação com os agês, visto que os agês são adquiridos pelos próprios tocadores e não pela tribo. O fato de a maioria ser "de religião" facilita a aquisição dos agês, segundo informaram, visto que a tribo não disponibiliza tais instrumentos. Supõe-se, portanto, que o maracá é um componente metonímico 
do "indígena" e o "agê" como elemento análogo ao segundo. O agê figura, assim como o corpo figura na dança, como locus de conexão entre diferentes dimensões: a religião de matriz africana e a tribo carnavalesca. $\mathrm{O}$ agê ${ }^{14}$ executa o mesmo tipo de sonoridade do maracá e participa como componente sonoro não apenas das tribos, mas também das casas de religião de matriz africana do Sul ${ }^{15}$. Aqui está um ponto criativo de articulação feito pelos integrantes da tribo "Os Comanches". "Sem os agês", disse o ensaiador da tribo, Cláudio Camisa, "não existe tribo", porque "o agê é de tribo indígena".

A história do instrumento, semelhante ao xequerê, sempre fora referenciada enquanto de origem "afro" pelos próprios comancheiros. Mas logo Camisa salientou: "é que o agê é usado na religião também pra saudar nossa ancestralidade negra, mas na tribo, aqui, ele é de índio". Destaco essa frase de Camisa, pois aponta para uma reflexão interessante. A função rítmica do instrumento funciona como um mediador que conecta duas dimensões convencionalmente não relacionadas, ao supor o maracá correspondendo à "cultura indígena". Com isso quero dizer que o toque do agê funciona como análogo ao maracá devido à função rítmica que conecta dois domínios, a saber, o contexto da religião afro-brasileira e o contexto carnavalesco da tribo indígena. $\mathrm{O}$ agê, reconhecido enquanto um instrumento "afro" pelos meus informantes porque é utilizado nas casas de religião, é "de índio" pois exerce a função do maracá.

Tal analogia necessita dos sentidos convencionais dados, da impressão de que o agê é "afro" e que o maracá é "indígena" como um dado último a manter a ordem do contexto. É a partir disso que se produz o deslocamento, a invenção, a metáfora: "O agê é indígena". Essa produção de metáfora ficou mais clara, para mim, quando aproximada do silogismo da grama de Bateson (1989, p. 38) em contraposição ao silogismo lógico. Seu raciocínio é pautado pela analogia (e a metáfora é a criação de analogias). Pautados por uma lógica substancialista vinculada à preocupação com a "origem", somos levados a pensar que o maracá é indígena, o agê não é maracá e, portanto, o agê não é indígena. Todavia, se seguirmos a lógica comancheira, teremos que descrever da seguinte maneira: indígena toca maracá. Agê produz o som de maracá. Logo, agê é indígena. O que está em jogo, portanto, não é o que se "é" - no sentido de origem -, mas o que "se faz com" o instrumento, ou seja, como ele funciona, eis aí a porosidade

14 Agê é instrumento feito com uma cabaça inteira trançada com cordão e contas diversas. No candomblé baiano é chamado afoxé.

15 Batuque é a religião de matriz africana existente no Rio Grande do Sul que cultua orixás. 
do sentido. Adiciono ainda o fato de que esse movimento reforça, ao utilizar agê como "de índio", a existência do contexto de onde ele supostamente é retirado: da religião "afro". Em todos os processos descritos, inventa-se, da mesma forma, a convenção.

\section{CONCLUSÃO}

O jogo implica em repetição - e anualmente a guerra é disputada. Implica certa estruturação específica, um acordo entre aqueles que dele participam de como funciona e qual suas possibilidades operativas. Implica uma série de estratégias de guerra e refinamento das armas (alegorias, fantasias, dança e ritmos) não apenas para realizar uma boa performance, mas, sobretudo, para ganhar a batalha na avenida. Implica uma ambiguidade inerente, como nos diz Bateson (1991), entre "mapa" e "território", e não é apenas explicado por relações externas a ele, mas produz relações no mundo. Envolve uma intensa improvisação dos sujeitos que dele participam, sentimentos de pertencimento, de doação, de dedicação: como fazer "crescer" a ideia de dona Georgina, o fascínio de Urbano de ver um trabalho seu na avenida, a sublimação de Rosane ao sentirse uma deusa ao dançar, ou o orgulho de Camisa pela invenção de um toque. Todos os exemplos de fuga de modelos instituídos - croquis, coreografias ou partituras previamente estipulados -, imersos em processos de improvisação (INGOLD, 2012, p. 38):

Improvisar é seguir os modos do mundo à medida que eles se desenrolam, e não conectar, em retrospecto, uma série de pontos já percorridos. [...] A vida está sempre em aberto: seu impulso não é alcançar um fim, mas continuar seguindo em frente. A planta, o músico ou o pintor, ao seguirem em frente, "arriscam uma improvisação".

Nesse processo, as invenções ocorrem. Concomitantes às criações das coisas, dos corpos e dos sons, em uma composição que extrapola o momento ritual da avenida, criam-se também os conceitos de "afro/negro" e de "índio". Essas invenções estão diretamente atreladas à rivalidade inerente à "guerra", motor central do jogo e suas ambivalências. Manifesta-se tanto na performance na avenida, por meio das alegorias, das fantasias e dos corpos com suas danças marchadas, onde as coisas ganham vida; nas avaliações sobre a criatividade da tribo rival e suas (in)capacidades de produzir as metaforizações necessárias para se fazer "índio", que implica a percepção de si como "mais índio" do que o 
outro; e nas aproximações cósmicas, como trouxe Rosane, entre guerreiros: os índios guerreiros e os orixás que vão para a guerra.

Entendo essas invenções como relações afroindígenas (GOLDMAN, $2014,2015)^{16}$. Não se trata com isso de derivar problemas genéticos - de busca de origem do que seria afro e indígena - nem da criação de tipologias para caracterizar esses termos. Relação afroindígena também não pretende subsumir um termo ao outro, nem supor uma fusão entre as partes - e está longe de ser uma identidade autoatribuída às tribos que, como já desenvolvi em outro trabalho (FLORES, 2017), não pensam-se afroindígenas, mas "negros" e “índios", a depender do contexto em que se encontram. Relação afroindígena trata-se de pensar a diferença enquanto diferença e seus fluxos, seus deslocamentos, portanto, suas concomitantes invenções no interior do jogo "guerra". Relação afroindígena, nesse caso, nomeia um movimento. Movimento, sobretudo, inerente ao jogo das tribos carnavalescas.

\section{REFERÊNCIAS}

ACSELRAD, M. Dançando contra o Estado: análise descoreográfica das forças em movimento entre os caboclinhos de Goiana/Pernambuco. Revista Nanduty, Dourados, v. 5, n. 6, p. 146-166, 2017.

ALMEIDA, R. Tablado folclórico. São Paulo: Ricordi, 1961.

ANJOS, J. C. Território da Linha Cruzada: a cosmopolítica afro-brasileira. Porto Alegre: Universidade Federal do Rio Grande do Sul (UFRGS), 2006.

BATESON, G. Pasos hacia uma ecologia de la mente. Buenos Aires: Ediciones Lohlé-Lumen, 1991.

BATESON, G. Naven. São Paulo: EDUSP, 2006.

16 Segundo Goldman (2014, 2015) sobre a "relação afroindígena": "Não se trata de gênese porque não se trata de determinar o que seria afro, o que seria indígena e o que seria resultado de sua mistura — ou, eventualmente, o que não seria nem uma coisa nem outra. E isso seja em um sentido propriamente biológico ou genealógico, seja em sentidos cultural, social etc. Não se trata de um problema de identidade. [...] Não é incomum, contudo, que ao evitar o fogo da gênese os antropólogos caiam na frigideira da tipologia onde, fingindo fazer abstração das conexões genéticas, acaba se chegando exatamente no mesmo lugar. Estabelecer um tipo (ideal ou não, pouco importa) afro puro, um tipo indígena puro, e quantos tipos intermediários forem, não é, de modo algum, o nosso propósito. Nem os modelos historicistas, explícitos ou disfarçados, nem os estrutural-funcionalistas (idem) nos parecem possuir qualquer utilidade aqui". 
BATESON, G.; BATESON, M. C. El mundo del proceso mental. In: BATESON, G.; BATESON, M. C. El temor de los ángeles. Barcelona: Gedisa, 1989. p. 29-42. CAVALCANTI, M. L. As alegorias no carnaval carioca: visualidade espetacular e narrativa ritual. Textos Escolhidos de Cultura e Arte Populares, Rio de Janeiro, v. 3, n. 1, p. 17-27, 2006.

CORREA, N. Os vivos, os mortos e os deuses. 1998. Dissertação (Mestrado em Antropologia Social) - Programa de Pós-Graduação em Antropologia Social, Universidade Federal do Rio Grande do Sul, Porto Alegre, 1998.

FLORES, L. A guerra comancheira: contribuições a uma antropologia afroindígena. R@U- Revista de Antropologia da UFSCar, São Carlos, v. 9, n. 2, p. 43-61, jul./dez. 2017.

GEIGER, A. Apresentação. In: BATESON. G. Naven. São Paulo: Edusp, p. 23-67, 2006.

GODI, A J. De índio a negro, ou o reverso. Cadernos CRH, Salvador: UFBA, v. 4, p. 51-70, 1991.

GOLDMAN, M. A relação afroindígena. Cadernos de Campo, São Paulo, n. 23, p. 213-222, 2014.

GOLDMAN, M. Quinhentos anos de contato: por uma teoria etnográfica da (contra)mestiçagem. Mana, Rio de Janeiro, v. 21, p. 641-659, 2015.

INGOLD, T. Trazendo as coisas de volta à vida: emaranhados criativos num mundo de materiais. Horizontes Antropológicos, Porto Alegre, v. 18, n. 37, p. 25-44, jan./jun. 2012.

MELLO, C. Política, meio ambiente e arte: percursos de um movimento cultural do extremo sul da Bahia. 2010. Tese (Doutorado em Antropologia Social) - Programa de Pós-Graduação em Antropologia Social, Museu Nacional, Universidade Federal do Rio de Janeiro, Rio de Janeiro, 2010.

PEREIRA, C. A. M. Cacique de Ramos: uma história que deu samba. Rio de Janeiro: Epapers Serviços Editoriais, 2002.

RISÉRIO, A. Carnaval Ijexá: notas sobre afoxés e blocos do novo carnaval afrobaiano. Salvador: Corrupio, 1981. 
SANTOS, C. O grito de Guerra dos Cabocolinhos: etnografia da performance musical da Tribo Canindé. 2008. Dissertação (Mestrado em Música) - Programa de Pós-Graduação em Artes, Universidade Federal da Paraíba, João Pessoa, 2008. SCHECHNER, R. Playing. The future of ritual. New York: Routledge, p. 24-44, 1995.

SCHUTZ, A. On multiple realities. Philosophy and Phenomenological Research, v. 5, n. 4, p. 533-576, 1945.

SILVA, A. C. C. da. Agenciamentos coletivos, territórios existenciais e capturas: uma etnografia de movimentos negros em Ilhéus. 2004. Tese (Doutorado em Antropologia Social) - Programa de Pós-Graduação em Antropologia Social, Museu Nacional, Universidade Federal do Rio de Janeiro, Rio de Janeiro, 2004.

SILVA, N. Composição e metamorfose no Maracatu da zona da mata de Pernambuco. 2018. Dissertação (Mestrado em Antropologia Social) - Programa de Pós-Graduação em Antropologia Social, Museu Nacional, Universidade Federal do Rio de Janeiro, Rio de Janeiro, 2018.

WAGNER, R. A invenção da cultura. São Paulo: Cosac Naify, 2010. 
